\title{
Exploring Potential of REDD+ Readiness with Social Safeguard through Diverse Forest Use Practices in Gunung Palung National Park in West Kalimantan, Indonesia
}

\author{
Toshihide Yoshikura $^{1 *}$, Masahiro Amano², Gusti Z. Anshari ${ }^{3}$ \\ ${ }^{1}$ Appropriate Agriculture International Co. Ltd., Tokyo, Japan \\ ${ }^{2}$ Faculty of Human Sciences, Waseda University, Saitama, Japan \\ ${ }^{3}$ Magister of Environment, Tanjungpura University, Pontianak, Indonesia \\ Email: *yoshikura@koushu.co.jp
}

How to cite this paper: Yoshikura, T., Amano, M., \& Anshari, G. Z. (2018). Exploring Potential of REDD+ Readiness with Social Safeguard through Diverse Forest Use Practices in Gunung Palung National Park in West Kalimantan, Indonesia. Open Journal of Forestry, 8, 141-154.

https://doi.org/10.4236/ojf.2018.82010

Received: January 9, 2018

Accepted: March 3, 2018

Published: March 6, 2018

Copyright $\odot 2018$ by authors and Scientific Research Publishing Inc. This work is licensed under the Creative Commons Attribution International License (CC BY 4.0).

http://creativecommons.org/licenses/by/4.0/

\begin{abstract}
Implementation is expected to be a measure for sustainable forest management by providing benefit for forest users based on their efforts. Without careful attention for the social safeguard, the mechanism of reducing greenhouse gas emissions from deforestation and forest degradation with forest management (REDD+) might cause negative impact such as depriving of customary forest use rights under unclear tenure and forest use rights typical in Indonesia. This study aimed to explore how REDD+ Safeguard can be applied in readiness activities by analyzing practical forest use situations in a conservation forest, the Gunung Palung National Park as study site. From the results of the questionnaire survey and interviews, characteristics of forest users were identified and compared. The households, mostly Malays, practicing traditional durian collection, were recognized as main forest users depending on on-farm income especially from non-timber forest product (NTFP). Since the income structure is relatively low and unstable, some of them practice farming in forest area or sell their forest use rights to other households. They are inclined to be lack in legal farm land and certain forest use rights. Based on the findings, consideration for diverse forest users and potential readiness activities were discussed and proposed. For achieving REDD+ implementation with sustainable forest management and social safeguard, it will be necessary to respect for customary rights and take comprehensive measures as readiness efforts.
\end{abstract}

\section{Keywords}

REDD+ Readiness, Safeguards, Forest Gardening, Gunung Palung National 
Park, NTFP, Forest Use Rights

\section{Introduction}

\subsection{Progress of REDD+ as Measures for Climate Change}

As a mitigation measure for global warming by conserving forest biomass, the mechanism of reducing greenhouse gas emissions from deforestation and forest degradation with forest management (REDD+) has been expected and discussed under the United Nations Framework Convention on Climate Change (UNFCCC). Even before that agreed, developing countries, which have needs for reducing deforestation and conserving forest resources, have promoted preparation for the REDD+ strategy and demonstrations by utilizing financial and technical supports from developed countries and international organizations such as the World Bank and the United Nations. In decision 1/CP16 of the UNFCCC in Cancun, Mexico, in 2010, activities for developing technical capacities and institutional arrangements to be implemented in step-by-step phases beginning with readiness strategy development and demonstration activities with toward achieving results-based actions and payment were encouraged (UNFCCC, 2010). As a part of REDD+ readiness in the phased approach, numerous pilot activities for capacity building and demonstrations have been initiated at various locations and jurisdictional scales. Besides that, parties have agreed to establish information system on social and environmental safeguards for REDD+ in order to avoid and mitigate negative consequences for the people living and precious ecosystem in regions, (REDD+ Safeguard) as determined by the Cancun Agreement (UNFCCC, 2010). In COP 23 under UNFCCC in 2017, all parties agreed to move from conceptual to technical achievement of the Paris Agreement, agreed to aiming at climate mitigation as an important decision for conservation of tropical forest, adopted in COP 21 (UNFCCC, 2015).

This template, created in MS Word 2007, provides authors with most of the formatting specifications needed for preparing electronic versions of their papers. All standard paper components have been specified for three reasons: 1) ease of use when formatting individual papers; 2) automatic compliance to electronic requirements that facilitate the concurrent or later production of electronic products; and 3) conformity of style throughout a journal paper. Margins, column widths, line spacing, and type styles are built-in; examples of the type styles are provided throughout this document and are identified in italic type, within parentheses, following the example. Some components, such as multi-leveled equations, graphics, and tables are not prescribed, although the various table text styles are provided. The formatter will need to create these components, incorporating the applicable criteria that follow.

\subsection{Progress of REDD+ Preparation in Indonesia}

Indonesia is the eighth largest forest area in the world, the third among the 
tropical countries. It also has extensive peatland forests pooling the largest carbon stock in the tropics. These forests experience a great rate of forest reduction; 684,000 ha of net loss was detected between 2010 and 2015 because of timber extraction and oil palm plantation (Edwards et al., 2012; FAO, 2015). Because of the destruction of its carbon-rich peatlands of around 69\% of greenhouse gas (GHG) emissions as a leading factor, which Indonesia ranks as the world's ninth largest GHG emitter, and is determined to take measures against global warming (Carlson et al., 2012; Matthews et al., 2014). Indonesia submitted the National Determined Contribution (NDC) to the UNFCCC in 2015 and is committed to reduce its GHG emissions by using a mechanism of Reducing Emission from Deforestation and Forest Degradation with Forest Management (REDD+) as one of measures for targeting reduction of GHG emissions by $26 \%$ compared to the current baseline by 2020 (RoI, 2015). As part of REDD+ readiness in Indonesia, various policy-related and project-based pilot activities have been implemented with the assistance of international and bilateral organizations. A Letter of Intent (LOI) for financial support that was signed between Indonesia and Norway in 2010 facilitated the set-up of the previous REDD+ Task Force and the decision on the moratorium on issuing palm oil licenses in forest areas and peatlands. Furthermore, the financing would also be utilized for promoting the set-up of sub-national financial mechanisms and pilot demonstrations (Luttrell et al., 2011; McNeill, 2015). Besides the support of the Government of Norway, multilateral programs and various REDD+ demonstrations, mostly mixed with policy supports in provincial and district governments have also been conducted by bilateral agencies, NGOs, and private companies.

\subsection{Challenges in REDD+ Implementation}

Since the Paris Agreement entered into force in 2016, the parties are expected to engage and promote preparatory measures for climate change including REDD+ (UNFCCC, 2015). While implementing REDD+ demonstration at the local level, previous studies raised land and forest tenures as one of the key challenges (McCarthy, 2004; Eilenberg, 2015; Saito-Jensen et al., 2015). The legal basis of the state control over forest areas in Indonesia has been based on the New Forestry Law (NFL) of 1999. Under the NFL, around 70\% of total land area has been assigned to forest zones under the jurisdiction of Ministry of Forestry (Brockhaus et al., 2012). However, it has generated ambiguity and inconsistencies in the jurisdictional status of land with the Basic Agrarian Law (BAL) of 1960 which had administrated the state control over the all lands in Indonesia. Especially, it caused unclear positions of customary rights for using forest area which was recognized in the BAL, but contested in the NFL (Resosudarmo et al., 2014). Under the ambiguous situations, customary practices have been continued in some forest areas by people depending on forest resources. Implementation of REDD+ can be a justification for forcing those people with ambiguous rights to leave forests and not to access to REDD+ benefit (Abram et al., 2017; Levang et al., 2016). In order to address those potential negative impact of REDD+, it is 
essential to consider REDD+ Safeguard and take appropriate measures as a readiness effort for areas of which has risk of conflict on forest use rights such as in Indonesia, majority of forest area is under the state control (Kusters et al., 2007; Mulyani \& Jepson, 2013; Agung et al., 2014).

\subsection{Purpose of the Study}

Under those situations, a common challenge for promoting REDD+ demonstrations and implementation would be to take effective actions for appropriate targets through identification of agents and drivers of deforestation and forest degradation (Kissinger et al., 2012; Minang et al., 2014). While local situations tend to be complex with various actors and unclear policies, some forest users who depend on natural resources such as non-timber forest products (NTFPs) would be in difficult conditions in case REDD+ was implemented without considering actual forest use conditions (Shackleton et al., 2011; Sunderlin et al., 2014; Eilenberg, 2015). Thus, this study aims to explore how REDD+ Safeguard, especially social aspect, can be applied to avoid negative impact of REDD+ implementation through analyzing practical forest use situations in a conservation forest, Gunung Palung National Park (GPNP) in Indonesia.

\section{Method}

\subsection{Study Area}

Gunung Palung National Park (GPNP), which is located in the southwest part of the West Kalimantan Province, Indonesia, was selected as a research site that has potential conflicts on land uses caused by unclear park boundary over communities surrounding the national park, and substantial increases of human pressures on expansive land uses. Annual rainfall was $2645 \mathrm{~mm}$ in 2013, with periods of reduced rainfall from January to March and August to October (BPS Kayong Utara, 2014). It covers 90,000 hectares of conservation forest (Hutan Konservasi) designated by the Ministry of Forestry (currently, Ministry of Environment and Forestry; "MoEF") in 1990 after registered as a Wildlife Sanctuary in the 1984 as precious ecosystem area enclosing peat swamp forest and habitats for Proboscis monkey (Nasalis larvatus) and Orangutan (Pongo pygmaeus wurmbii). Local people have traditionally used forest area mainly for collecting and cultivating non-timber forest products (NTFP) such as durian, coffee and latex from traditional and small rubber plantation. Salafsky (1994) defined it as "Forest Gardens (Kebun Hutan)" which are a variant of the traditional home garden that had been developed by the local communities in response to the development of new economic markets. Even after GPNP office demarcated boundary in 1984, practices of forest gardening continued without sufficient information and consultation on the locations and consultation on the national park boundary. In the previous study (Yoshikura et al., 2016), harvest of the forest garden in Sedahan Jaya, one of the GPNP vicinity, exhibited 309.4 ton of carbon stock with 1,125 trees, mostly Durio, per hector. 
Even though illegal logging was the main cause of deforestation in the 1990's, it has decreased owing to strengthened patrolling activities by the GPNP office (Hiller et al., 2004; Zamzani, 2008). In addition to urbanization and population growth, oil palm plantations in the GPNP vicinity have been increasing; local people are hired for laborers, and huge areas of farmland and forest are converted into oil palm plantations (Lawrence et al., 1998; Ravenel, 2004). Under those situations, MoEF initiates a REDD+ readiness activities around the GPNP since 2013.

Currently, around 45,000 people, comprising various ethnic groups like Malay, Dayak, Javanese, Bugis, Madura, and Chinese, live in 20 villages that share boundaries with the GPNP and are located in two districts-Ketapang and Kayong Utara. According to consultation with the GPNP office through a preliminary field survey, the villages (Desa) in the Sukadana sub-district (Kacama$\tan$ ) was selected as the target area because there are relatively large numbers of households have practiced agriculture activities and forest uses. In the sub-district, population growth was around $2.6 \%$ between 2010 and 2013 (BPS Kayong Utara, 2014).

\subsection{Data Collection and Analysis}

The questionnaire survey was implemented to elicit quantitative information, such as types and amounts, within five main survey sections: basic information (family size and ethnicity), assets (livestock and land use), farming conditions (types of crops, productivity, location of farming), collection of non-timber forest products (NTFP; type of NTFP, amount, location of collection), and income structure (amount from on-farm and off-farm activities). Even though there are totally ten villages in the Sukadana sub-district, the eight villages were targeted for the questionnaire survey excluding two villages, Sutera and Harapan Mulia, those are nearby a town and rare in forest uses. From the eight sample villages, the total 610 samples (13.8\%) were selected out of 4421 total households (BPS Kayong Utara, 2014). The sample data was analyzed to understand features of the sample households through comparing the characteristics of livelihoods and forest uses. Households for the survey were selected by using a stratified sampling method, which extracts characteristics of various ethnic groups, farming types, and livelihood types by referring to village profile statistics. According to the stratified number of ethnic groups, farming types, and livelihood types in each village, sample households were selected through consultation with village leaders. Following the questionnaire survey, semi-structured interviews aiming to obtain supplemental information on the forest use practices and the park management was done with forest users and GPNP office staff. These surveys and interviews were conducted from October 2014 to March 2015. In the statistical analysis, basic socio-economic characteristics of the sample households were calculated by forest use and farming types. Further analysis was proceeded by comparing the income structure and using analysis of variance (ANOVA) to explore key socio-economic variables of each type. 


\section{Results}

\subsection{Overview of Socio-Economic Conditions}

The socio-economic conditions of the sample households can be summarized as follows. Major ethnic groups were Malays, around 64\%, followed by Madula, Bugis, Jawa and Bali. Main livelihood activity was paddy farming engaged by $68 \%$ of the households with 1.4 ton per hector of average annual production. While the average area for farming was 0.7 hector, 54 households, $8 \%$ of the total, has cultivated farm land inside the national park. Main livestock is poultry, engaged by $55 \%$ of the households, and cow by $12 \%$ of the households by grazing in their residential area. The average annual income was 30 million Indonesia Rupiah per household, around 2400 US dollars as of rate in 2014. Most of them, $89 \%$ of the samples, acquire their income by both farming and non-farming activities such as daily labors for construction- or transport-related jobs. Regarding to the forest use activities, 233 households, 38.2\%, possessed forest gardening or planation mainly for traditional NTFP collection and rubber tapping. Forest gardens for durian and sugar palm have been traditionally conducted inside the national park mainly by the Malay inhabitants those who inherited durian trees (Durio zibethinus). They have customary user rights for the durian trees but not for land. Rubber plantations mostly outside the national park are also common but come to be rarely managed due to its low market price. The villagers, practicing rubber plantations, explore alternative income activities such as fishery and off-farm activities. However, some of them convert the rubber to farm or expand farming into forest area even inside the national park. While 166 households, 27.2\%, get cash income by selling NTFPs like durian, 87 households, $14.3 \%$, manage rubber plantations for income.

According to the interview to villagers, strict patrol by the GPNP office cause concerns and dissatisfaction of the community that sufficient explanation and information sharing have not been provided. When interviewed the GPNP field staff, most of the staff have not recognized exactly where the park boundaries demarcated in 1984. The park boundary demarcation is in responsible of the Forest Area Development Bureau (BPKH), which has divisions in each province and a role of managing geographic data of the all conservation forests over Indonesia. Thus, the GIS experts in the GPNP office do not possess the map data due to inefficient information sharing across the organizations. Besides that, almost all park staff have not been updated on the locations and related regulations of park zonings allocated in 2011. It can be a main reason why the park staffs are reluctant to talk with communities about the park boundaries and zonings. Due to this situation, ambiguous forest uses such as forest gardening inside the national park have been connived without clear understanding on regulations both for the GPNP staff and villagers. Actually, traditional forest use can be allowed as Special Use in the zoning regulation, the stakeholders do not recognize well what kind of forest use can be allowed by which definition of traditional use. 


\subsection{Characteristics of Forest Users}

Out of the total samples, 233 households (38.2\%) use forest area either inside or outside the national park. In this study, they were categorized in the three forest use types: 1) non-forest users, and forest users 2) inside or 3) outside the national park. By the forest use type, key socio-economic characteristics of users were compared and summarized in Table 1. The Malays those who have practiced traditional forest gardening seem to have the privileges in forest uses in terms of the higher engagement ratio in the Malay and low in the immigrants seen in Type II. In addition to that, the households of Type II show larger average figures in forest use and farming area compared with the other types. In the both forest users, Type II and III, the majorities engage in paddy cropping. However, the engagement rate of forest use is common in the on-farm activities, and Type II shows higher rate; NTFP collection (65.8\%) than rubber plantations in Type III (48.7\%). Additionally, the average of total income is the lowest in the Type II, which was IDR 29.1 million. It explains that domestic uses of NTFP by the forest users, mostly the Malays in Type II, bear a role of safety net for the people those who are lower in cash income. When compared details of the income structure by using a box plot in Figure 1, the Type II shows smaller differences of income among households. It would imply that the people, mainly forest users, have relatively similar economic conditions.

In order to confirm statistical differences of sample households in the three forest use types, ANOVA was applied for key socio-economic attributes and described in Table 2. Regarding to land asset, significant differences are exhibited in forest garden area as well as farm area. It would explain that the larger land asset of Type II, as seen in Table 1, is relatively remarkable. Even though remarkable difference is not observed in paddy rice production, there are significant differences in income from on-farm activities and NTFP selling. Thus, it can be said that the on-farm income in Type II is benefited from collection and selling of NTFP, mainly durian, not from paddy production. This result supports the essential role of forest use and NTFP collection for the Type 2 users, mainly Malays who have practiced traditional forest gardening.

\subsection{Potential Agents of Deforestation and Forest Degradation}

As noted in the above 3.1, some households, $8 \%$ of the sample, conduct farming inside the national park. They can be recognized as potential agents of deforestation

Table 1. Socio-economic conditions of sample households by forest use type.

\begin{tabular}{|c|c|c|c|c|c|c|c|c|c|c|}
\hline \multirow{3}{*}{$\begin{array}{c}\text { Forest use } \\
\text { type }\end{array}$} & \multirow{3}{*}{$\mathrm{N}$} & \multirow{3}{*}{$\begin{array}{c}\text { Malay } \\
(\%)\end{array}$} & \multirow{3}{*}{$\begin{array}{c}\text { Immigrant } \\
(\%)\end{array}$} & \multicolumn{2}{|c|}{ Land asset } & \multicolumn{3}{|c|}{ Engagement rate } & \multirow{2}{*}{\multicolumn{2}{|c|}{$\begin{array}{l}\text { Total income } \\
\text { (Million Rp.) }\end{array}$}} \\
\hline & & & & FG area & $\begin{array}{c}\text { Farm } \\
\text { area }\end{array}$ & Paddy & NTFP & Rubber & & \\
\hline & & & & (ha) & (ha) & $(\%)$ & (\%) & (\%) & Average & S.D. \\
\hline 1) Non user & 377 & 62.9 & 30.5 & - & 0.71 & 56.2 & 14.9 & 5.0 & 30.9 & 31.9 \\
\hline 2) Inside NP & 114 & 91.2 & 17.5 & 0.76 & 0.73 & 71.1 & 65.8 & 8.8 & 29.1 & 24.1 \\
\hline 3) Outside NP & 119 & 47.9 & 19.3 & 0.74 & 0.64 & 72.3 & 29.4 & 48.7 & 31.0 & 27.0 \\
\hline
\end{tabular}

Rp: Indonesia Rupiah. 
Table 2. ANOVA on key socio-economic attributes by forest use type.

\begin{tabular}{|c|c|c|c|c|c|c|c|c|c|c|}
\hline \multirow{3}{*}{\multicolumn{2}{|c|}{$\begin{array}{c}\text { Socio-economic } \\
\text { attributes }\end{array}$}} & \multirow{3}{*}{ Unit } & \multirow{2}{*}{\multicolumn{2}{|c|}{$\begin{array}{l}\text { 1) Non user } \\
(\mathrm{n}=377)\end{array}$}} & \multirow{2}{*}{\multicolumn{2}{|c|}{$\begin{array}{l}\text { 2) Inside NP } \\
(\mathrm{n}=114)\end{array}$}} & \multirow{2}{*}{\multicolumn{2}{|c|}{$\begin{array}{l}\text { 3) Outside NP } \\
(\mathrm{n}=119)\end{array}$}} & \multirow{3}{*}{ F ratio } & \\
\hline & & & & & & & & & & \\
\hline & & & Average & S.D. & Average & S.D. & Average & S.D. & & \\
\hline \multirow[b]{2}{*}{ Land asset } & FG area & ha & 0.0 & 0.0 & 0.8 & 0.5 & 0.7 & 0.8 & 216.2 & ** \\
\hline & $\begin{array}{l}\text { Farm } \\
\text { area }\end{array}$ & ha & 0.4 & 0.6 & 0.6 & 0.6 & 0.5 & 0.6 & 2.3 & * \\
\hline \multirow[t]{3}{*}{$\begin{array}{l}\text { Agricultural } \\
\text { production }\end{array}$} & $\begin{array}{l}\text { Paddy } \\
\text { rice }\end{array}$ & Ton/year & 1.0 & 1.4 & 1.0 & 1.4 & 0.8 & 1.0 & 1.2 & \\
\hline & Total & $\begin{array}{l}\text { Million } \\
\text { Rupiah }\end{array}$ & 30.9 & 31.8 & 29.1 & 24.1 & 31.0 & 26.9 & 0.2 & \\
\hline & On-farm & $\begin{array}{l}\text { Million } \\
\text { Rupiah }\end{array}$ & 10.4 & 13.5 & 11.4 & 7.2 & 14.1 & 14.6 & 3.4 & * \\
\hline \multirow{2}{*}{ Income } & NTFP & $\begin{array}{l}\text { Million } \\
\text { Rupiah }\end{array}$ & 0.8 & 4.4 & 3.1 & 5.0 & 1.5 & 3.5 & 12.1 & ** \\
\hline & Off-farm & $\begin{array}{l}\text { Million } \\
\text { Rupiah }\end{array}$ & 19.8 & 30.5 & 14.6 & 23.1 & 14.6 & 13.7 & 2.6 & * \\
\hline \multicolumn{11}{|c|}{${ }^{*} p<0.01,{ }^{*} p<0.1 ; \mathrm{df}=(2,607)$} \\
\hline
\end{tabular}

FG: Forest Garden.

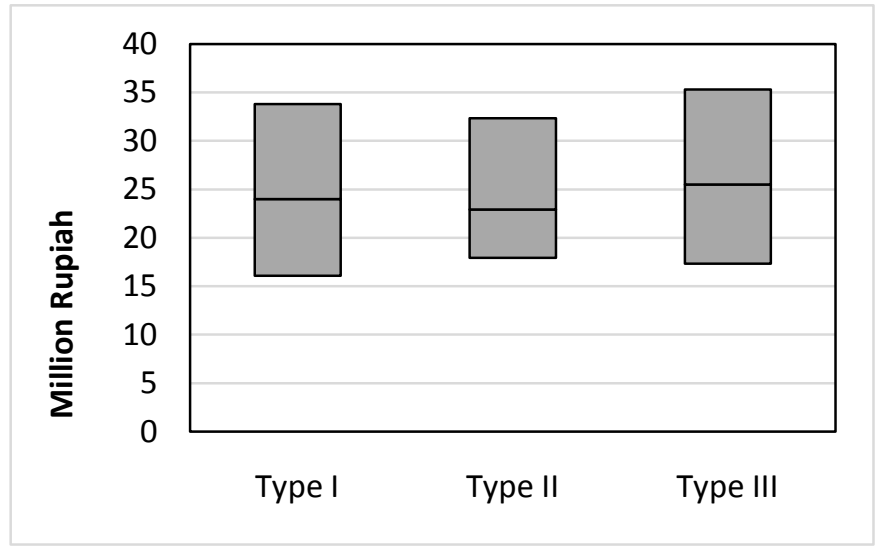

Figure 1. Box plot on total income by forest use type.

and forest degradation in this target area. According to the interview with several villagers, those households who practice farming inside the national park can be categorized in four types: 1) new immigrants or natives began to open new farmland in forest or ex-forest fire areas; 2 ) some Malay or Dayak people continue traditional shifting cultivation even inside the national park; 3) Non-Malay people such as Balinese or Javanese purchase user rights of forest area from the Malays; and 4) households, mostly the Malays, those who have practiced forest gardening start to farm in their forest garden area. Most of the interviewees pointed out that lack of sufficient farming area inside villages could be underlying causes of such encroachment of forest area, and it tends to be accelerated when on-farm and NTFP dependent cannot get sufficient food or income from their agricultural production. 
Socio-economic characteristics of the households conducting farming inside the national park was compared with those of households conduct farming outside NP and all farming samples (Table 3). Relatively higher figures can be seen in rate of Malay (87.0), forest garden area $(0.92 \mathrm{ha})$, and engagement rate in NTFP collection (44.4\%). It mostly matches with the features of forest users, Type II in Table 1. When focused on the farm area, the households conduct farming inside the national park use remarkably small area, 0.14 ha in average, outside the national park. Actually, only 7 out of 54 households possess farm land outside the national park. They are not the Malays, but Balinese or Javanese. So, it can be applied in type 3) in the above of interview results. The others, 47 households, are mostly Malays and applied in the type 2) those who continue traditional shifting cultivation, and 4) those who shift from forest gardening to farming. Regarding to their residential places of those farming households, 89 percent is constituted by residents in two villages. Thus, it can be estimated that there is a kind of regionality or other specific causes in distribution of those potential agents.

For clarifying income situations of the household conduct farming inside the national park, accumulated graph by main income factors are prepared and compared with that of all farming and non-farming households (Figure 2). It reveals that the households are low in cash income and depend in agricultural activities such as paddy and other farm-related production including NTFP. Among them, there are households to get income also from off-farm permanent jobs such as personal stores and traders. However, those households those who get relatively stable income are limited in half of them. Most of the households farming inside the national park are lack in legal land asset and difficult to initiate own off-farm business by accessing to official financial service. In case they lose use rights for accessing land inside the national park by implementation of REDD+, they could lose their main income and fall into poverty.

\section{Discussion}

\subsection{Diversity and Changes in Forest Use}

Forest use practices by local people are so diverse and have changed according to socio-economic opportunities. While an increase in the role of forest resources as a cash income for local livelihoods, there are serious concerns that local

Table 3. Socio-economic conditions of sample households by farming place.

\begin{tabular}{|c|c|c|c|c|c|c|c|c|c|}
\hline \multirow{3}{*}{ Households } & \multirow{3}{*}{$\mathrm{N}$} & \multirow{3}{*}{$\begin{array}{c}\text { Malay } \\
(\%)\end{array}$} & \multirow{3}{*}{$\begin{array}{c}\text { Immigrant } \\
(\%)\end{array}$} & \multirow{2}{*}{ FG area } & \multicolumn{2}{|c|}{ Farm area (ha) } & \multicolumn{3}{|c|}{ On-farm activities } \\
\hline & & & & & Inside & Outside & Paddy & NTFP & Rubber \\
\hline & & & & (ha) & NP & NP & (\%) & (\%) & (\%) \\
\hline Farming in NP & 54 & 87.0 & 25.9 & 0.92 & 0.69 & 0.14 & 85.2 & 44.4 & 16.7 \\
\hline $\begin{array}{c}\text { Farming outside } \\
\text { NP }\end{array}$ & 376 & 58.2 & 75.3 & 0.70 & 0.00 & 0.70 & 87.5 & 28.5 & 16.5 \\
\hline All farming & 423 & 61.9 & 25.1 & 0.74 & 0.09 & 0.61 & 87.0 & 29.8 & 16.8 \\
\hline
\end{tabular}




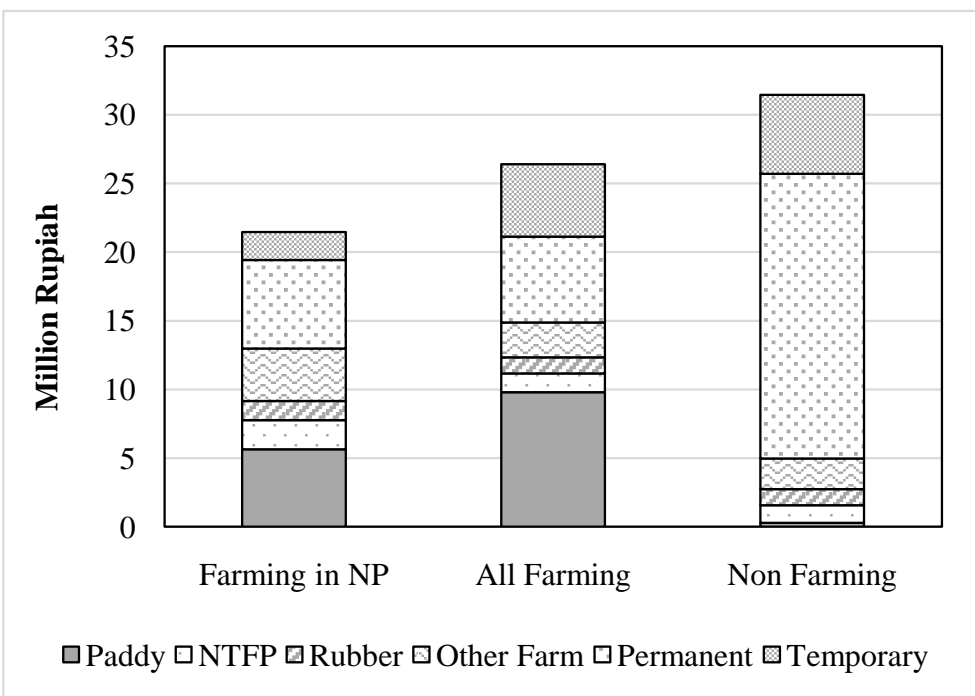

Figure 2. Differences of income and its composition for farming and non-farming samples.

people expand their farms into the park area due to lack of farming area, and shortages of farm incomes. From the result of socio-economic situation of forest users (Table 1) and ANOVA by forest use type (Table 2), it was recognized that the forest users inside the national park are largely the Malays those who depend on on-farm income especially from NTFP collection such as durian. The livelihoods of those forest users are mostly from agricultural activities and relatively low (Figure 1). In case their farm production was unstable or insufficient, their forest use and usage rights could be converted to farm uses or sold to other households as seen in Table 3 and interview results. Without appropriate measures against this trend, deforestation and forest degradation could be increased due to expansion of farming activities into forest area.

While REDD+ is considered as one of the measures in the study area, the traditional forest uses can be excluded since their rights are ambiguous. Besides that, the households farming inside the national park will be also prohibited since most of them do not own legally secured farms. Exclusion of those local people would cause not only leakage of deforestation but also violation of REDD+ safeguards. Previous study (Yoshikura et al., 2016) in the area exhibited relatively higher recovery of carbon stock from severe forest fire in the village practicing traditional forest gardening when compared with the other village conducting rubber plantation as main forest use. It implies that traditional forest use can contribute to maintain carbon stock or mitigate carbon loss. In order to achieve forest management with REDD+ Safeguards in the target area, It would be desirable to enroll the traditional forest users as primary stakeholders by providing appropriate rights and role for the users.

\subsection{Implications for REDD+ Readiness}

As described in the Background section, unclear rights for use forest is a common challenge in Indonesia and is observed in the study area. The main forest 
uses around the GPNP is traditional forest gardening mainly for durian collection inside the national park. Besides that, those areas tend to be used even for farming activities. Those practices are caused by unclear rights and boundary for the national park management. Even if those forest users were derived of use rights, it would not be a solution as far as their livelihoods depend on agriculture activities and forest products. By involving the forest users in forest management and mitigating forest uses by promoting alternative livelihoods, it can be good opportunity to move toward preparations for REDD+ with consideration for the Safeguards.

In case of the study area, main agents for deforestation and forest degradation can be identified such as the households practicing traditional forest gardening and conducting farming inside the national park. Besides that, all on-farm households can be potential agents in the long period since they have concerns with unstable agricultural production and lack of farm land. Thus, the following REDD+ readiness activities could be proposed in the study area:

1) Targeting for traditional forest users

Through respect for rights as noted in the REDD+ Safeguard, participation of the forest users for forest management can be promoted. In the process, collaborative forest management balanced with appropriate forest uses need to be introduced.

2) Targeting for the households conducting farming inside the national park

Mutual discussion and confirmation of forest boundary between government staff and the households will be needed. Through the process, common rule on forest use can be made and agreed. At the same time, capacity building on off-farm income activities and livelihood management could be essential to reduce pressures of expanding farm land.

3) Targeting for the households depend on agriculture activities as main livelihoods

For managing stable agricultural production in the current farms, support for increase of productivity will be important. However, lack of farming lands will be not solved while population increases in the area. Thus, it would be essential to provide capacity building and support for diversifying livelihood activities which do not depend on the traditional farming practices.

In addition to the above measures for each agent, capacity building for local government staff will be also necessary to provide appropriate official service with clear understanding on REDD+ Safeguards. To make those activities sustainable, distribution of REDD+ benefit will be expected. By channelling REDD+ benefit for sustainability of those activities, it will be expected that the forest users and community people refrain from selling their customary rights to the wealth and converting farm to oil palm plantation that is expanding around the GPNP.

\section{Conclusion}

To explore how REDD+ Safeguard can be effective to avoid negative impact of 
REDD+ implementation such as excluding customary forest users, socio-economic survey was conducted for sample households in target villages around the GPNP. By comparing characteristics of forest users, the households, mostly the Malays, practicing traditional durian collection was recognized that their livelihoods depend on on-farm income especially from NTFP. Since the income structure is relatively low and unstable, some of them practice farming in forest area or sell their forest use rights to other households. Further analysis on the households conducting farming inside the national park revealed that the underlying cause of such farming practice would be lack of legal farm land without certain rights. Based on those findings, importance of the REDD+ Safeguards and involving the forest users in forest management were discussed, and potential REDD+ readiness activities were proposed. Even though this study focused only in a case of the GPNP, it revealed that characteristics of forest users and potential agents of deforestation and forest degradation are diverse in customary practices and income structure. It will be critical to consider tenure issues such as customary forest use and legal farm land as REDD+ readiness activities for achieving REDD+ implementation with sustainable forest management and social safeguard.

\section{Acknowledgements}

We acknowledge support from the Indonesia-Japan project for the Development of the REDD+ Implementation Mechanism (IJ-REDD+) implemented by Japan International Cooperation (JICA) and Ministry of Forestry and Environment. We would also like to thank the staff in the Gunung Palung National Park office for supporting our survey. Those organizations and individuals responsible for primary data collection bear no responsibility for the analysis and interpretations presented herein.

\section{References}

Abram, N. K., Meijaard, E., Wilson, K. A., Davis, J. T., Wells, J. A., Ancrenaz, M., Budiharta, S., Durrant, A., Fkhruzzi, A., Runting, R.K., Gaveau, D., \& Mengersen, K. (2017). Oil Palm-Community Conflict Mapping in Indonesia: A Case for Better Community Liaison in Planning for Development Initiatives. Applied Geography, 78, 33-44. https://doi.org/10.1016/j.apgeog.2016.10.005

Agung, P., Galudra, G., Van Noordwijk, M., \& Maryani, R. (2014). Reform or Reversal: The Impact of REDD+ Readiness on Forest Governance in Indonesia. Climate Policy, 14, 748-768. https://doi.org/10.1080/14693062.2014.941317

BPS Kayong Utara (2014). Kabupaten Kayong Utara Dalam Angka 2014 (Kayong Uatara District in Figures 2014). Sukadana, Indonesia: Badan Putsat Statistics Kabupaten Kayong Utara.

Brockhaus, M., Obidzinski, K., Dermawan, A., Laumonier, Y., \& Luttrell, C. (2012). An Overview of Forest and Land Allocation Policies in Indonesia: Is the Current Framework Sufficient to Meet the Needs of REDD+? Forest Policy and Economics, 18, 30-37. https://doi.org/10.1016/j.forpol.2011.09.004

Carlson, K. M., Curran, L. M., Ratnasari, D., Pittman, A. M., Soares-Filho, B. S., Asner, G. 
P., \& Rodrigues, H. O. (2012). Committed Carbon Emissions, Deforestation, and Community Land Conversion from Oil Palm Plantation Expansion in West Kalimantan, Indonesia. Proceedings of the National Academy of Sciences of the United States of America, 109, 7559-7564. https://doi.org/10.1073/pnas.1200452109

Edwards, D. P., Koh, L. P., \& Laurance, W. F. (2012). Indonesia's REDD+ Pact: Saving Imperilled Forests or Business as Usual? Biological Conservation, 151, 41-44. https://doi.org/10.1016/j.biocon.2011.10.028

Eilenberg, M. (2015). Shades of Green and REDD: Local and Global Contestations over the Value of Forest versus Plantation Development on the Indonesian Forest Frontier. Asia Pacific Viewpoint, 56, 48-61. https://doi.org/10.1111/apv.12084

FAO (2015). Global Forest Resources Assessment 2015: How Are the World Forest Changing? Rome: Food and Agriculture Organization of the United Nations.

Hiller, M. A., Jarvis, B. C., Lisa, H., Paulson, L. J., Pollard, E. H. B., \& Stanley, S. A. (2004) Recent Trends in Illegal Logging and a Brief Discussion of Their Causes: A Case Study from Gunung Palung National Park, Indonesia. Journal of Sustainable Forestry, 19, 181-212. https://doi.org/10.1300/J091v19n01_09

Kissinger, G., Herold, M., \& De Sy, V. (2012). Drivers of Deforestation and Forest Degradation: A Synthesis Report for REDD+ Policymakers. Vancouver: Lexeme Consulting.

Kusters, K., De Foresta, H., Ekadinata, A., \& Van Noordwijk, M. (2007). Towards Solutions for State vs. Local Community Conflicts over Forestland: The Impact of Formal Recognition of User Rights in Krui, Sumatra, Indonesia. Human Ecology, 35, 427-438. https://doi.org/10.1007/s10745-006-9103-4

Lawrence, D., Peart, D. R., \& Leighton, M. (1998) The Impact of Shifting Cultivation on a Rainforest Landscape in West Kalimantan: Spatial and Temporal Dynamics. Landscape Ecology, 13, 135-148. https://doi.org/10.1023/A:1007985915187

Levang, P., Riva, W. F., \& Orth, M. G. (2016). Oil Palm Plantations and Conflict in Indonesia: Evidence from West Kalimantan. In R. Cramb, \& J.F. McCarthy (Ed.), The Oil Palm Complex: Smallholders, Agribusiness and the State in Indonesia and Malaysia (pp. 283-300). Singapore: NUS Press.

Luttrell, C., Obidzinski, K., Brockhaus, M., Muharrom, E., Petkova, E., Wardell, A., \& Halperin, J. (2011). Lessons for REDD+ from Measures to Control Illegal Logging in Indonesia. CIFOR.

Matthews, H. D., Graham, T. L., Keverian, S., Lamontagne, C., Seto, D., \& Smith, T. J. (2014). National Contributions to Observed Global Warming. Environmental Research Letters, 9, Article ID: 014010. https://doi.org/10.1088/1748-9326/9/1/014010

McCarthy, J. F. (2004). Changing to Gray: Decentralization and the Emergence of Volatile Socio-Legal Configurations in Central Kalimantan, Indonesia. World Development, 32, 1199-1223. https://doi.org/10.1016/j.worlddev.2004.02.002

McNeill, D. (2015). Norway and REDD+ in Indonesia: The Art of Not Governing? Forum for Development Studies, 42, 113-132.

Minang, P. A., Van Noordwijk, M., Duguma, L. A., Alemagi, D., Do, T. H., Bernard, F., Agung, P., Robiglio, V., Catacutan, D., Suyanto, S., Armas, A., Aguad, C.S., Feudjio, M., Galudra, G., Maryani, R., White, D., Widayati, A., Kahurani, E., Namirembe, S., \& Leimona, B. (2014). REDD+ Readiness Progress across Countries: Time for Reconsideration. Climate Policy, 14, 685-708.

Mulyani, M., \& Jepson, P. (2013). REDD+ and Forest Governance in Indonesia: A Multistakeholder Study of Perceived Challenges and Opportunities. The Journal of Envi- 
ronment \& Development, 22, 261-283. https://doi.org/10.1177/1070496513494203

Ravenel, R. M. (2004). Community-Based Logging and De Facto Decentralization: Illegal Logging in the Gunung Palung Area of West Kalimantan, Indonesia. Journal of Sustainable Forestry, 19, 213-237. https://doi.org/10.1300/J091v19n01_10

Republic of Indonesia (RoI) (2015). Intended Nationality Determined Contribution Submitted to UNFCCC.

http://www4.unfccc.int/submissions/INDC/Published\%20Documents/Indonesia/1/IN DC_REPUBLIC\%20OF\%20INDONESIA.pdf

Resosudarmo, I. A. P., Atmadja, S., Ekaputri, A. D., Intarini, D. Y., Indriatmoko, Y., \& Astri, P. (2014). Does Tenure Security Lead to REDD+ Project Effectiveness? Reflections from Five Emerging Sites in Indonesia. World Development, 55, 68-83. https://doi.org/10.1016/j.worlddev.2013.01.015

Saito-Jensen, M., Sikor, T., Kurniawan, Y., Eilenberg, M., Setyawan, E. P., \& Kustini, S. J. (2015). Policy Options for Effective REDD+ Implementation in Indonesia: The Significance of Forest Tenure Reform. International Forestry Review, 17, 86-97. https://doi.org/10.1505/146554815814725040

Salafsky, N. (1994). Forest Gardens in the Gunung Palung Region of West Kalimantan, Indonesia. Agroforestry Systems, 28, 237-268. https://doi.org/10.1007/BF00704759

Shackleton, S., Delang, C. O., \& Angelsen, A. (2011). From Subsistence to Safety Nets and Cash Income: Exploring the Diverse Values of Non-Timber Forest Products for Livelihoods and Poverty Alleviation. In Non-Timber Forest Products in the Global Context (pp. 55-81). Berlin Heidelberg: Springer.

https://doi.org/10.1007/978-3-642-17983-9_3

Sunderlin, W. D., Larson, A. M., Duchelle, A. E., Resosudarmo, I. A. P., Huynh, T. B., Awono, A., \& Dokken, T. (2014). How Are REDD+ Proponents Addressing Tenure Problems? Evidence from Brazil, Cameroon, Tanzania, Indonesia, and Vietnam. World Development, 55, 37-52. https://doi.org/10.1016/j.worlddev.2013.01.013

UNFCCC (2010). The Cancun Agreements: Outcome of the Work of the Ad Hoc Working Group on Long-Term Cooperative Action under the Convention. Decision 1/CP.16, Cancun.

UNFCCC (2015). Paris Agreement. Decision 1/ Cp.21, Paris.

http://unfccc.int/files/essential_background/convention/application/pdf/english_paris_ agreement.pdf

Yoshikura, T., Amano, M., Hikichi, K., Supriyanto, B., \& Wardhana, D. (2016). Effects of Forest Use by Local People in Livelihoods and Ecosystem: Exploring Co-Benefits in the Gunung Palung National Park, Indonesia. Waseda Journal of Human Sciences, 29, 181-192.

Zamzani, F. (2008). Process of Deforestation and Agricultural Expansion in Gunung Palung National Park, West Kalimantan, Indonesia. Submitted in Partial Fulfillment of the Requirements for the Degree of Master of Environmental Sciences, in the Master's Program in Environmental Sciences, Tsukuba: University of Tsukuba. 